\title{
Effect of a health claim on consumer acceptance of milk-based dessert containing
}

\section{omega-3}

\author{
Efeito de uma alegação de saúde na aceitação do consumidor de sobremesa à base de leite contendo \\ ômega-3
}

Efecto de una declaración de propiedades saludables en la aceptación por parte del consumidor de un postre a base de leche que contiene omega-3

\author{
Marina Carvalho Martins Madalão \\ ORCID: https://orcid.org/0000-0001-8897-5109 \\ Federal University of Viçosa, Brazil \\ E-mail: marina_cmartins@yahoo.com.br \\ Andrea Alves Simiqueli \\ ORCID: https://orcid.org/0000-0002-2750-1417 \\ Federal University of Viçosa, Brazil \\ E-mail: andrea.simiqueli@ufv.br \\ Tarcísio Lima Filho \\ ORCID: https://orcid.org/0000-0002-2794-5544 \\ Federal University of Espírito Santo, Brazil \\ E-mail: tarcisiolimaf@yahoo.com.br \\ Márcia Cristina Teixeira Ribeiro Vidigal \\ ORCID: https://orcid.org/0000-0002-8065-0753 \\ Federal University of Viçosa, Brazil \\ E-mail: marcia.vidigal@ufv.br \\ Luis Antonio Minim \\ ORCID: https://orcid.org/0000-0002-1584-9117 \\ Federal University of Viçosa, Brazil \\ E-mail:1minim@ufv.br \\ Valéria Paula Rodrigues Minim \\ ORCID: https://orcid.org/0000-0001-7143-2060 \\ Federal University of Viçosa, Brazil \\ E-mail: vprm@ufv.br
}

\begin{abstract}
This study was to evaluate the influence of information on the addition of omega- 3 and its health benefits in the acceptance of dairy dessert. The hedonic thresholds methodology was applied in two trials: blind and open-label. In the blind trial, no information was provided to consumers regarding the formulation of the flans. In the open-label trial, consumers received the information on the addition of omega- 3 and its health benefits. The value of compromised acceptance threshold (CAT) was not influenced by the information on the addition of omega-3 and its health benefits. However, there was a high increase in the value of hedonic rejection threshold (HRT) when the consumers were informed of the benefits of omega-3, and it was possible to increase the addition of the compound in the flans by up to $21.03 \%$ without causing product rejection, confirming the positive effect of information on health benefits in accptance.

Keywords: Non-sensory characteristics; Polyunsaturated fatty acids; Hedonic threshold methodology; Compromised acceptance threshold; Hedonic rejection threshold.

\section{Resumo}

Este estudo teve como objetivo avaliar a influência das informações sobre a adição de ômega-3 e seus benefícios para a saúde na aceitação de sobremesa láctea. A metodologia de limiares hedônicos foi aplicada em dois ensaios: cego e com informação. No ensaio cego, nenhuma informação foi fornecida aos consumidores sobre a formulação dos flans. No ensaio com informação, os consumidores receberam informações sobre a adição de ômega-3 e seus benefícios para a saúde. $\mathrm{O}$ valor do limite de aceitação comprometido (LAC) não foi influenciado pelas informações sobre a adição de ômega-3 e seus benefícios para a saúde. Porém, houve um grande aumento no valor do limiar de rejeição hedônica (LRH) quando os consumidores foram informados dos benefícios do ômega-3, sendo possível aumentar a adição do composto nos flans em
\end{abstract}


até $21,03 \%$ sem causar rejeição do produto, confirmando o efeito positivo da informação sobre os benefícios para a saúde na aceitação.

Palavras-chave: Características não sensoriais; Ácidos graxos poliinsaturados; Metodologia dos limiares hedônicos; Limiar de aceitação comprometido; Limiar de rejeição hedônica.

\section{Resumen}

Este estudio tuvo como objetivo evaluar la influencia de la información sobre la adición de omega-3 y sus beneficios para la salud en la aceptación del postre lácteo. La metodología de umbrales hedónicos se aplicó en dos ensayos: ciego y abierto. En el ensayo ciego, no se proporcionó información a los consumidores sobre la formulación de los flanes. En el ensayo de etiqueta abierta, los consumidores recibieron información sobre la adición de omega-3 y sus beneficios para la salud. El valor del umbral de aceptación comprometido (UAC) no se vio influenciado por la información sobre la adición de omega-3 y sus beneficios para la salud. Sin embargo, hubo un alto aumento en el valor del umbral de rechazo hedónico (URH) cuando se informó a los consumidores de los beneficios del omega-3, y fue posible aumentar la adición del compuesto en los flanes hasta en un $21.03 \%$ sin provocando el rechazo del producto, confirmando el efecto positivo de la información sobre los beneficios para la salud en la aceptación.

Palabras clave: Características no sensoriales; Ácidos grasos poliinsaturados; Metodología de umbral hedónico; Umbral de aceptación comprometido; Umbral de rechazo hedónico.

\section{Practical Applications}

Omega-3 (EPA and DHA) has unpleasant sensory characteristics that difficult its addition to foods. However, non-sensory characteristics, such as health benefits, also influence food acceptance. Consumer interest in health-related issues has increased significantly in recent years. This research is unprecedented on the use of HTM to determine the influence of health benefits on hedonic thresholds. These results provide important data for food industries and consumers, as it indicates the maximum amount of omega-3 that can be added to foods without changing acceptance or causing sensory rejection.

\section{Introduction}

Traditional sensory analysis, which studies the sensory characteristics arising from the balance of food composition, is essential to ensure its quality standard. However, it is insufficient to meet the quality requirements of the dynamic food market. The optimized product formulation is indeed necessary for successful innovation and acceptance. Consumers, however, are also influenced by other factors during the process of choosing, purchasing, or accepting food (Minim, 2018).

Among the non-sensory characteristics, the concern with health and the consequent interest of consumers in more nutritious foods stand out. Studies show that information about the addition of the nutrient and its health benefits has great relevance in product acceptance (Monahan et al., 2017; Vidigal et al., 2011).

Lima Filho et al $(2015,2017$ e 2018) aimed to meet the demand for hedonic thresholds proposed and validated the hedonic thresholds methodology (HTM). This methodology allowed us to determine two new affective thresholds: the compromised acceptance threshold (CAT) and the hedonic rejection threshold (HRT). CAT is defined as the intensity of the stimulus in which changes in the sensory acceptance of the product begin to occur. The HRT is the stimulus intensity at which sensory rejection of the product begins, that is, the transition point between acceptance and sensory rejection.

HTM proved to be effective to assess the reduction of sucrose, butter, and sodium in foods (Gamba et al., 2021; Gamba et al., 2020, Santana et al., 2020), and for the addition of nutrients such as ferrous sulfate (Simiqueli et al., 2019). However, there are no reports in the literature on the application of HTM to assess the influence of non-sensory characteristics on hedonic thresholds.

Based on the above, the present study aimed to evaluate the effect of information on the addition of omega- 3 and its health benefits on acceptance in hedonic thresholds of compromised acceptance and hedonic rejection, in dairy desserts, flan type, strawberry flavor added with Omega 3 (EPA e DHA). Importantly, omega-3 plays important roles in the development and functioning of organs, in addition to being a precursor of anti-inflammatory mediators, and acts in the prevention of heart disease 
(Maki et al., 2017; Maurício et al., 2017; Adkins \& Kelley 2010), diabetes (Shilpa et al., 2020), Alzheimer's (Yan et al., 2020; Belkouch et al., 2016), anemia (Daak et al., 2020) and Parkinson's (Tamtaji et al., 2019), in addition to cancer control (Abedi et al., 2020; Story, 2020)and cholesterol reduction (Olson \& Aryana, 2017; Comunian \& Favaro-Tindade, 2016; Let et al., 2007). However, because it gives an unpleasant taste to foods, its insertion becomes a challenge for the food industry. Thus, it is of fundamental importance to study the influence of the health benefits of omega-3 on hedonic thresholds, aiming at the development of a new product with functional properties without compromising sensory acceptability.

\section{Methodology}

This study was conducted at the Laboratório de Propriedades Tecnológicas e Sensoriais dos Alimentos at Universidade Federal de Viçosa (UFV), under the approval of the Human Research Ethics Committee of UFV (process number 077164/2019).

Employing two trials, blind and open-label, the influence of the information on the addition of omega- 3 and its health benefits on the acceptance and on the values of hedonic thresholds in a strawberry-flavored dairy dessert was evaluated. In preliminary tests with several products, strawberry-flavored dairy dessert was selected, because in this product the characteristic flavor of ômega-3 was better masked.

In the blind trial, the flan samples were encoded with random three-digit numbers and no information was given to consumers regarding the formulation of the flans. In the open-label trial, consumers received the information on the addition of omega-3 and its health benefits when evaluating the samples. The results were analyzed by comparing the hedonic thresholds (CAT and HRT) obtained in both tests, and the analysis of variance. The flan-type dairy dessert was chosen due to the high consumption and acceptance of individuals of different age groups and simple preparation.

\subsection{Materials}

Omega-3 (EPA and DHA, Vitafor $\left.{ }^{\circledR}\right)$, condensed milk (Piracanjuba $\left.{ }^{\circledR}\right)$, sour cream (Piracanjuba $\left.{ }^{\circledR}\right)$, strawberry-flavor gelatin (Royal ${ }^{\circledR}$ ), strawberry essence (fine line ${ }^{\circledR}$ ) were used obtained in the local market in the city of Viçosa, Minas Gerais.

\subsubsection{Preparation of strawberry-flavored flans}

The flans formulations control (without addition of omega-3) and stimulus (with addition of omega-3) were composed of condensed milk, cream, filtered water, gelatin with strawberry flavor and strawberry essence (Table 1). The addition of omega3 was performed only in the stimulus samples (Table 1). In preparation, gelatin was previously dissolved in water at $100{ }^{\circ} \mathrm{C}$ and then added to the other ingredients and homogenized for two minutes in a Philips Walita Duravita $800 \mathrm{~W}$ blender, at speed 5. The flans were placed in $50 \mathrm{ml}$ plastic cups at a temperature of $8^{\circ} \mathrm{C}$ until the sensory test was conducted.

Omega-3 oil had its mass discounted in the mass of sour cream in each formulation. Omega-3 concentrations were defined considering the recommended daily intake (1 $\mathrm{g}$ of omega-3). 
Table 1. Formulation of strawberry-flavored flans.

\begin{tabular}{|c|c|c|c|c|c|c|}
\hline & Condense & & & Strawberry- & Strawberry & \\
\hline Sample & milk & Milk cream & Water & flavored gelatin & essence & Ômega-3 \\
\hline Control & 34.000 & 34.000 & 28.000 & 3.000 & 1.000 & 0.000 \\
\hline Stimulus 1 & 34.000 & 33.950 & 28.000 & 3.000 & 1.000 & 0.050 \\
\hline Stimulus 2 & 34.000 & 33.775 & 28.000 & 3.000 & 1.000 & 0.225 \\
\hline Stimulus 3 & 34.000 & 33.600 & 28.000 & 3.000 & 1.000 & 0.400 \\
\hline Stimulus 4 & 34.000 & 33.425 & 28.000 & 3.000 & 1.000 & 0.575 \\
\hline Stimulus 5 & 34.000 & 33.250 & 28.000 & 3.000 & 1.000 & 0.750 \\
\hline
\end{tabular}

* All figures are expressed in\%. Source: Authors (2021).

\subsection{Consumers}

The sensory panels in both trials (blind and open-label) were composed of 120 regular consumers of flan-type dairy dessert, recruited at the UFV, Minas Gerais.

The consumer team in the blind trial was composed of 63 women and 57 men aged between 18 and 62 years. In the openlabel trial, the consumer team consisted of 69 women and 51 men aged between 18 and 67 years.

\subsection{Methods}

\subsubsection{Hedonic Threshold Methodology - Blind trial}

To determine the thresholds of compromised acceptance (CAT) and hedonic rejection (HRT) of flans, we applied the hedonic thresholds methodology (HTM) developed and validated by Lima Filho et al. (2015, 2017, 2018). First, 120 consumers conducted five acceptance test sessions. In each session, consumers received two flan samples encoded with three-digit numbers: a control sample, with no omega-3, and a stimulus sample, added with omega-3. Within each pair, the samples were randomized, and among the pairs, the samples were served in ascending order of omega-3 concentration in the stimulus sample.

Participants were instructed to taste the samples from left to right and to evaluate how much they liked or disliked each product in relation to the overall impression, using the 9-point hedonic scale form, where 1 corresponds to "I disliked it extremely" and 9 to "I liked it extremely" (Minim et al., 2018).

\subsubsection{Hedonic Threshold Methodology - open-label trial on the addition of omega-3 and its health benefits}

We applied the open-label trial with the information on the addition of omega- 3 and its health benefits similarly to the blind trial. However, the 120 consumers were first instructed to read the information on the benefits of omega-3 (Figure 1), which remained in the consumer cabin throughout the assessment.

The information provided was obtained based on scientific articles that proved the relationship of omega-3 to the reduction of total cholesterol and LDL (Olson \& Aryana, 2017; Comunian \& Favaro-Tindade, 2016; Let et al., 2007), prevention of diseases such as diabetes (Shilpa et al., 2020), Alzheimer (Yan et al., 2020; Belkouch et al., 2016), and neurodegenerative 
diseases (Kerdiles et al., 2017). In addition to having anti-inflammatory properties (Singer et al., 2008), contributing to cancer control (Abedi et al., 2020; Story, 2020) and contributing to athetic performance (Visconti et al., 2021).

Figure 1. Information about the benefits of omega-3.

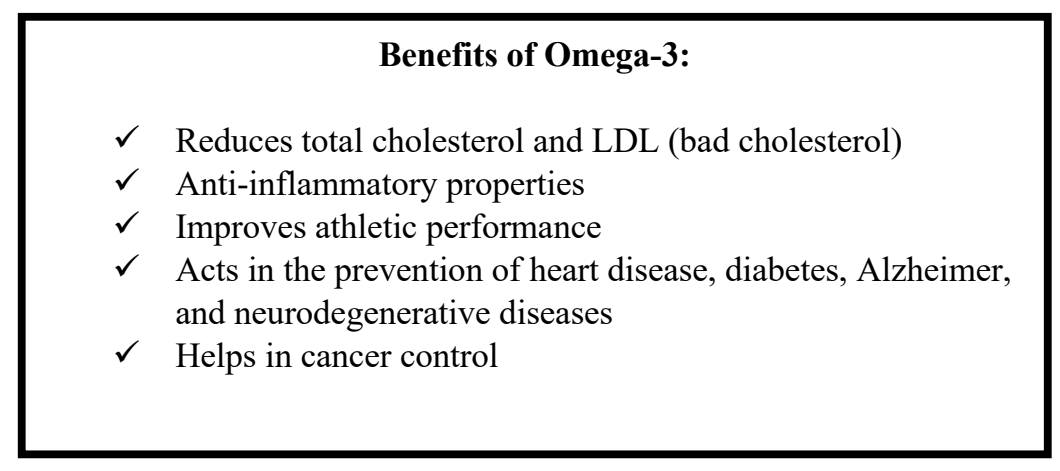

Source: Authors (2021).

In addition to the informative, we also code the samples differently to the blind trial. The control samples received the identification of "Flan" and the other samples, with the addition of omega-3 $(0.050 \mathrm{~g} ; 0.225 \mathrm{~g} ; 0.400 \mathrm{~g} ; 0.575 \mathrm{~g}$ and $0.750 \mathrm{~g})$, were identified with "Flan with $0.050 \mathrm{~g}$ of omega-3", "Flan with $0.225 \mathrm{~g}$ of omega-3", "Flan with $0.400 \mathrm{~g}$ of omega-3", "Flan with $0.575 \mathrm{~g}$ of omega-3", and "Flan with $0.750 \mathrm{~g}$ of omega-3", respectively.

\subsection{Statistical analysis}

\subsubsection{Comparison of hedonic averages in each session}

To assess the significance between hedonic notes of the stimulus samples obtained in the blind and open-label trails, the analysis of variance was performed in a randomized block design $(\alpha=5 \%)$. In this way, the hedonic scores of the stimulus samples of each session were compared in both trials, blind and with open-label on the addition of omega-3 and its health benefits.

Statistical analysis was performed using the free software R, version 3.5.3.

\subsubsection{Determination of CAT and HRT in blind and open-label trials}

Through the hedonic notes obtained with the analysis of the samples, one CAT and one HRT were determined for each assay.

In each test, for statistical analysis of CAT determination, for each session, the $t$-test for paired samples was performed, comparing the hedonic note of the control sample with the hedonic note of the stimulus sample. With the $t$ values obtained in each session, a graph of the $t$ value (y-axis) was drawn up as a function of the omega- 3 concentrations of the stimulus samples (x-axis). A regression model was fitted to the data, considering the significance of the regression parameters and the determination coefficient $\mathrm{R}^{2}$ (SSregression/SStotal).

The CAT value was calculated using the regression model equation, corresponding to the concentration of omega- 3 in which the calculated $t$ value is equal to the tabulated $t$ value ( $\mathrm{p}=0.05 ; 119$ consumers). This means that from that point on, the change in sensory acceptance of the product begins. Thus, the tabulated $t$ value (1.9801) was replaced by the y in the equation to obtain the value of $x$, which corresponds to the CAT, that is, the added omega- 3 concentration in which sensory acceptance impairment begins to occur of the flan. 
In each trial, for statistical analysis and determination of the HRT, a graph was drawn up with the average of the hedonic notes of the stimulus samples obtained in each session ( $\mathrm{y}$-axis) as a function of the omega-3 concentrations ( $\mathrm{x}$-axis). A regression model was adjusted, considering the same criteria used to select the CAT model.

The HRT was calculated using the regression model equation, with the cut-off point corresponding to the hedonic note 5 (hedonic term "indifferent"), indicating the beginning of the sensory rejection of the product. The variable y of the adjusted model was replaced by 5 and the value of $x$, corresponding to the HRT, was calculated, that is, it is the concentration of omega3 at which sensory rejection of the strawberry flan begins to occur.

\section{Results}

\subsection{Comparison of hedonic averages in each session}

Table 2 shows the averages of the hedonic scores of the stimulus samples obtained in each session, in the blind trials and open-label trails on the addition of omega-3 and its health benefits. We observe that the information had no influence on the hedonic notes of the samples with $0.05 \%$ and $0.75 \%$ omega- 3 , the samples having the lowest and highest concentration of omega3 , respectively. That is, for such samples there was no influence of the information on the addition of omega-3 and its health benefits on the acceptance of the product at the level of $5 \%$ probability by the $\mathrm{F}$ test.

In the flan samples containing intermediate concentrations of omega-3 $(0.225,0.400$ and 0.575$)$, the hedonic notes of the stimulus samples differed at the level of 5\% probability by the $\mathrm{F}$ test in the different tests (blind and open-label), presenting a higher hedonic note. In the open-label trial, thus showing the positive effect of the information on the addition of omega- 3 and its health benefits, which contributed to greater acceptance of the product with these concentrations of omega-3.

Table 2. Comparison of averages of the hedonic notes of the stimulus samples in the blind and open-label trails.

\begin{tabular}{cccc}
\hline Concentration of omega-3 $(\% \mathrm{~m} / \mathrm{m})$ & Assay & Average hedonic grade & $p$-value \\
\hline \multirow{2}{*}{0,050} & Open-label & $8,0 \mathrm{a}$ & 0,051 \\
& Blind & $7,8 \mathrm{a}$ & \\
\hline \multirow{2}{*}{0,225} & Open-label & $7,1 \mathrm{a}$ & $\mathbf{0 , 0 0 1}$ \\
& Blind & $5,9 \mathrm{~b}$ & \\
\hline \multirow{2}{*}{0,400} & Open-label & $6,3 \mathrm{a}$ & $\mathbf{0 , 0 0 1}$ \\
& Blind & $5,2 \mathrm{~b}$ & \\
\hline \multirow{2}{*}{0,575} & Open-label & $4,7 \mathrm{a}$ & $\mathbf{0 4 1}$ \\
& Blind & $4,1 \mathrm{~b}$ & 0,749 \\
\hline \multirow{2}{*}{0,750} & Open-label & $3,5 \mathrm{a}$ & \\
\hline
\end{tabular}

Means followed by the same letter, within each concentration, do not differ by the F test ( $p>0.05)$. Source: Authors (2021).

\subsection{Hedonic thresholds}

Figure 2 shows the calculated t-values (y-axis) as a function of omega- 3 concentrations ( $\mathrm{x}$-axis), in the blind trial and open-label trail on the addition of omega-3 and its health benefits. For both tests, the model that best fitted the data was the first order (Table 3), considering the significance of the regression parameters $(p \leq 0.05)$ and determination coefficients greater than or equal to $92 \%$. 
Figure 2. Values of t calculated as a function of the omega-3 concentrations of the stimulus samples, in the blind and openlabel trails.

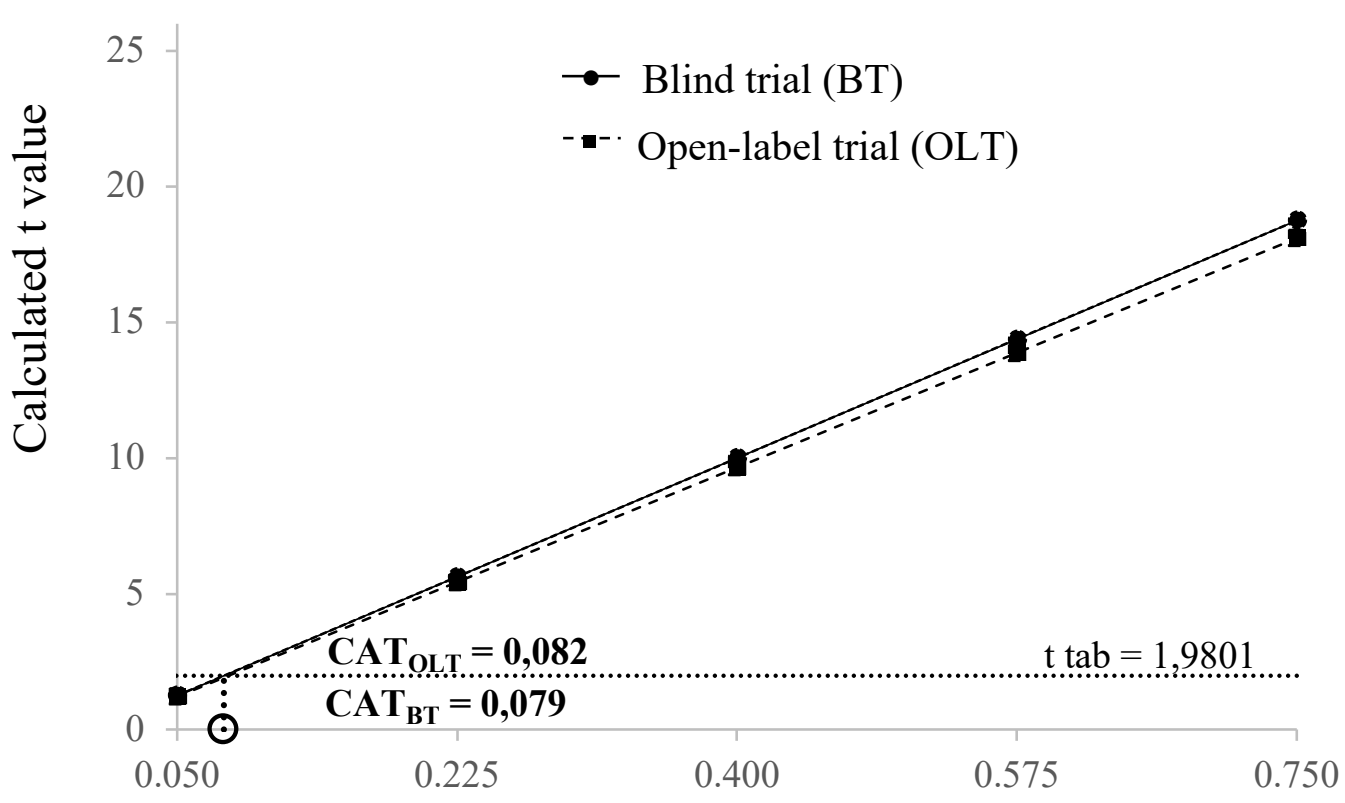

Omega-3 concentration $(\mathrm{g} / 100 \mathrm{~g})$

Source: Authors (2021).

The dotted line represents the tabulated $t$-value after which there is a significant difference in relation to acceptance (GL $=119 ; \mathrm{p}=0.05)$.

Table 3. Adjusted models and their respective determination coefficients to obtain the compromised acceptance threshold (CAT)

\begin{tabular}{ccc}
\hline Assay & Equation & $\mathrm{R}^{2}$ \\
\hline Blind & $\mathrm{Y}=25,0000 \mathrm{x}$ & 0,9308 \\
Open-label & $\mathrm{Y}=24,1314 \mathrm{x}$ & 0,9283 \\
\hline
\end{tabular}

Source: Authors (2021).

To determine the compromised acceptance threshold (CAT), the y of the model was replaced by the tabulated $t$ value (1.9801), calculating the CAT values of $0.079 \mathrm{~g}$ of omega-3/100 $\mathrm{g}$ of flan, for the blind trial and $0.082 \mathrm{~g}$ of omega-3/100 $\mathrm{g}$ of flan for the open-label trial. Therefore, the CAT values were similar. The CAT values represent the concentration from which there is a significant reduction in the sensory acceptance of the flans, which means that the addition of omega- 3 in a concentration below the CAT values does not alter the acceptance of the product.

To assess the influence of information on the hedonic rejection threshold value, a graph of the values of the hedonic grades (y-axis) was drawn up as a function of the omega-3 concentrations (x-axis) in the blind and open-label trials (Figure 3). 
For both tests, the model that best fitted the data was the first order (Table 4), considering the significance of the regression parameters $(p \leq 0.05)$, the determination coefficients greater than $96 \%$.

Figure 3. Average hedonic notes as a function of the omega-3 concentrations of the stimulus samples, in the blind and openlabel trails on the addition of omega- 3 and its benefits.

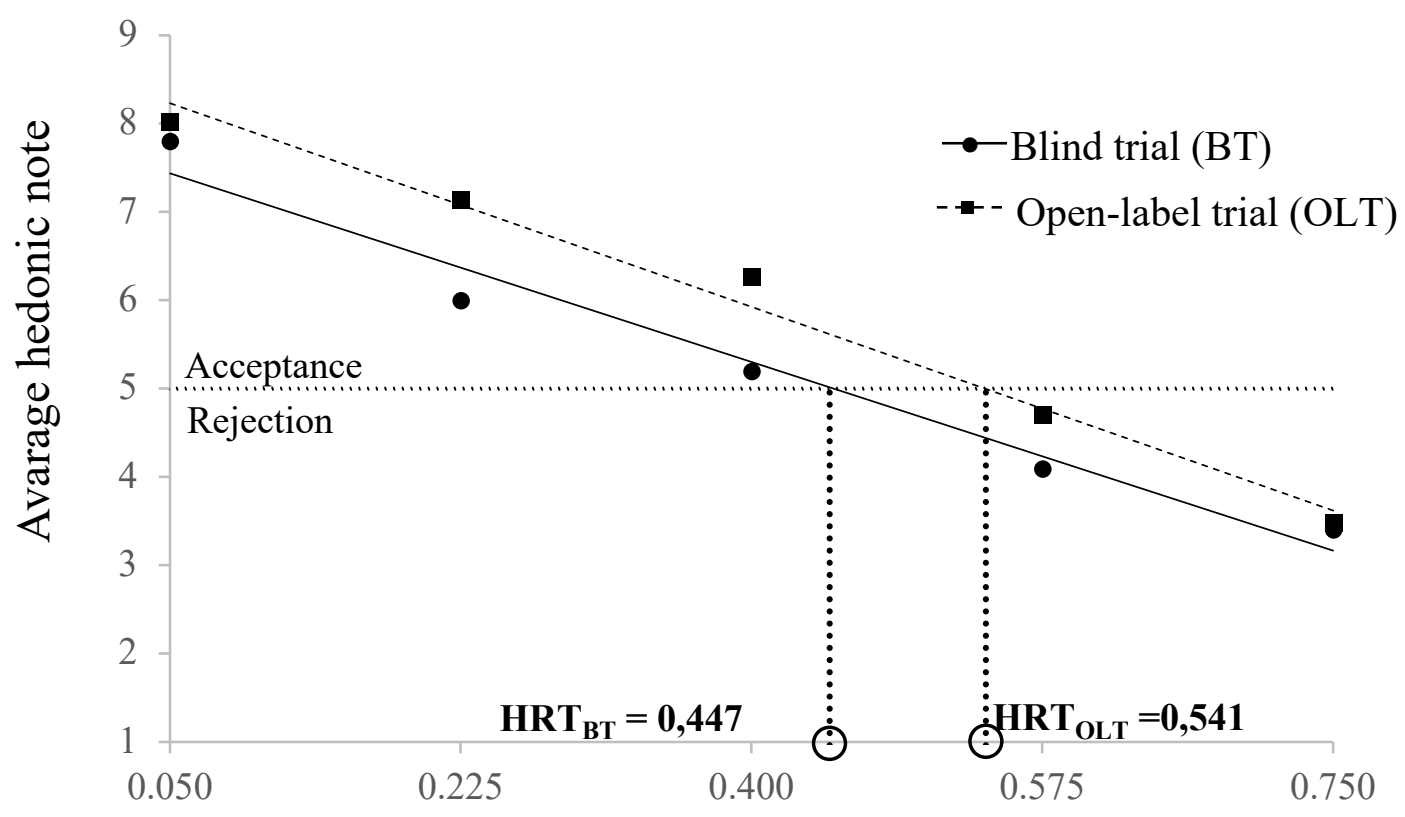

Omega-3 concentration $(\mathrm{g} / 100 \mathrm{~g})$

Source: Authors (2021).

The dotted line represents the hedonic note 5, corresponding to the term "indifferent", the beginning of sensory rejection.

Table 4. Adjusted models and their respective determination coefficients for obtaining the hedonic rejection threshold (HRT).

\begin{tabular}{ccc}
\hline Assay & Equation & $\mathrm{R}^{2}$ \\
\hline Blind & $\mathrm{Y}=-6,1029 \mathrm{x}+7,7431$ & 0,9697 \\
Open-label & $\mathrm{Y}=-6,5885 \mathrm{x}+8,5614$ & 0,9861 \\
\hline
\end{tabular}

Source: Authors (2021).

The value of the HRT was calculated by replacing the value of $\mathrm{y}$ in the model with 5 (corresponding to the hedonic term "indifferent") and by calculating the value of variable y (value of the HRT) (Table 4). Thus, the HRT values of 0.447 and 0.541 $\mathrm{g}$ of omega-3/100 $\mathrm{g}$ of flan were obtained in trials without and with information on the addition of the compound and its health benefits, respectively. Such values represent the concentration of omega-3 from which the sensory rejection of the product begins. 
It was observed that when consumers were informed about the addition of omega-3 and its health benefits, the HRT value was higher than when consumers were unaware of the addition of the compound. Therefore, by informing the consumer about the addition of omega-3 and its health benefits, it is possible to add even more omega-3 without resulting in sensory rejection of the strawberry flan.

The HRT models (Table 4) were used to verify the average hedonic grades of a strawberry flan with concentrations of omega-3 related to the CAT of each assay. For this, variable y of the model was replaced by the CAT value of the respective trails (Table 4, Figure 2). In the blind trial, a sample with an omega-3 concentration referring to LACEC, would have a hedonic average equal to 7.3, on a 9-point scale, ranging from "I liked it moderately" to "I liked it a lot". Considering the model of the open-label trail, this sample would have a hedonic average equal to 8.0, corresponding to the term "I liked it a lot", demonstrating a positive effect of information on product acceptance.

\section{Discussion}

In the evaluation of the average of hedonic notes of the stimulus samples (Table 2), we observe that the acceptance of flans containing $0.05 \mathrm{~g}$ of omega-3/100 g of flan does not differ between blind and open-label trails, therefore, information influenced the acceptance of flans containing $0.05 \mathrm{~g} / 100 \mathrm{~g}$. This may have happened due to the low concentration of omega-3, which is not enough to alter the sensory characteristics and, therefore, resulted in high acceptance by the samples, regardless of the presence of the information.

Numerically, the hedonic scores of all stimulus samples were higher in the open-label trials in relation to the blind trials. In addition, in sessions 2, 3 and 4, this difference is significant (Table 2). In sessions 2 and 3 the product was accepted, and this acceptance was even greater in the open-label trial, showing the positive influence of knowledge on the benefits of omega-3. In session 4 , it is possible to observe that there was a rejection, but the information still has a positive influence on the hedonic note of the sample containing $0.575 \mathrm{~g}$ of omega-3 per $100 \mathrm{~g}$ of flan since there is less rejection of the product in the open-label trail. This shows that despite the unpleasant taste conferred by omega-3 in this concentration, consumers were influenced by information about the addition of omega- 3 and its health benefits.

In session 5 , when $0.75 \mathrm{~g} / 100 \mathrm{~g}$ of omega- 3 was added to the product, no influence of the information on the hedonic note was observed, due to the unpleasant taste conferred by the high concentration of omega-3. Thus, the fact that consumers are aware of the health benefits of omega-3 was not enough to alter their rejection, also demonstrating the influence of sensory characteristics. This result corroborates with the results found by Vidigal et al. (2011) when assessing the influence of information on the health benefits of exotic juices. The authors concluded that camu-camu juice was rejected in both blind and open-label trials due to the unpleasant taste of the fruit.

When investigating the influence of information on the compromised acceptance threshold (CAT), it was observed that when consumers were unaware of the addition of the compound, the CAT value was $0.079 \mathrm{~g}$ of omega-3/100 $\mathrm{g}$ of flan. When consumers were informed about the addition of omega- 3 and its health benefits, the CAT value was $0.082 \mathrm{~g}$ of omega-3/100 $\mathrm{g}$ of flan (Figure 2). Thus, we observe that value of the CAT was not influenced by the information about the addition of omega3 and its health benefits. The hedonic averages referring to the concentrations of CAT were 7.26 in the blind trial and 8.02 in the open-label trial, indicating that in both tests the flans containing omega-3 in the CAT concentrations showed sensory acceptance.

Simiqueli et al. (2019) determined the hedonic thresholds (CAT and HRT) in strawberry flans added with ferrous sulfate without providing information on the addition of the compound. When added directly, both the value of CAT ( $0.00097 \mathrm{~g}$ FeSO4/100 g flan) and HRT (0.1274 g FeSO4/100 g) were lower than those found in this study $(0.079 \mathrm{~g}$ omega-3/100 $\mathrm{g}$ and $0.477 \mathrm{~g}$ of omega-3/100 g), which indicates the unpleasant taste of ferrous sulfate, even more intense than that of omega-3. 
With the increase in the concentration of omega-3 added to the flan, the thresholds of hedonic rejection (HRTs) are obtained, which consists of the intensity of the stimulus from which the sensory rejection of the product begins. As shown in Figure 3, the HRTs values were positively influenced by the information on the addition of omega-3 and its health benefits, since the supply of this information to the consumer allowed an increase of $21.03 \%$ in the concentration of omega- 3 in the dessert to start sensory rejection of the product. This increase was determined by comparing the difference between the values of the HRTs of the blind and open-label trials.

Through the HTM, it was possible to observe the range of concentrations in which the reversal of the rejection of the product occurs (between 0.447 and 0.541 ), in these concentrations the product was rejected in the blind trial and is now accepted in the open-label trial.

The addition of omega-3 in the flans from the concentration referring to the CAT and lower than the one referring to the HRT indicates that the product had its acceptance altered in relation to the control sample, although it is still accepted. Thus, the flan added with 0.225 and $0.400 \mathrm{~g}$ of omega- $3 / 100 \mathrm{~g}$ has acceptance, but this differs from the acceptance of the control flan.

Regardless of the assay, samples containing concentrations of 0.575 and $0.750 \mathrm{~g}$ of omega- 3 per $100 \mathrm{~g}$ of flan, showed concentrations of omega-3 higher than the HRT ( 0.447 and $0.541 \mathrm{~g}$ of omega-3 per $100 \mathrm{~g}$ of flan) (Figures 2 and 3 ), that is, these samples were sensorially rejected and the presence of information about the addition of omega- 3 and its health benefits did not allow the reversion of the rejection for sensory acceptance by these samples.

Considering the recommended daily intake (RDI) of omega-3 (EPA and DHA) of $1 \mathrm{~g}$ (Couet et al., 2001; Agostoni et al., 2012), the CATs values obtained in the blind and open-label trials, for $100 \mathrm{~g}$ of product, correspond to 7.9 and $8.2 \%$ of the RDI of omega-3, respectively, which allows it to be considered by the legislation as an "added" product of omega-3. For the product to be considered "enriched" or "fortified" the addition of the compound must occur at least $30 \%$ of the RDI in the case of solid foods. Using the equations in Table 3, it appears that a product containing $0.30 \mathrm{~g}$ of omega-3 per $100 \mathrm{~g}$ of flan $(\mathrm{x}=0.3)$ would have a hedonic score equal to 5.9 in the blind test, next to the hedonic term "I liked it slightly", and 6.6 in the essay with information, placing between the terms "I liked it slightly" and "I liked it moderately". Thus, it is observed that it is possible to add omega-3 in sufficient concentrations to be considered "enriched" or "fortified" maintaining the sensory acceptance of the flan. In addition, it appears that the acceptance of this product will be even greater if the consumer is informed about the benefits of adding omega-3. Although the addition of strawberry aroma was the only strategy in an attempt to mask the unpleasant sensory characteristics inherent in omega-3, it was possible to add the compound in sufficient concentrations so that the flan could be characterized as enriched or fortified without causing sensory rejection to the product.

Comparing the values of the HRTs with the RDI, it is observed that it is possible to add concentrations lower than 44.7 and $54.1 \%$ of the omega-3 RDI to the flan without and with information, respectively. This allows to characterize the flan as an "enriched" or "fortified" product with omega-3 (Brasil, 1998).

The effect of health benefits on the acceptance of flans containing omega- 3 can be associated with the fact that, currently, the population has been increasingly concerned with health, and has tried to live healthier, being, therefore, willing consuming healthier foods (Euromonitor Intrnational, 2017). Several studies have also found the influence of non-sensory characteristics, especially information on the addition of compounds to health benefits in the acceptance of products, showing that when consumers are informed about the presence of such compounds, acceptance tends to increase (Monahan et al., 2017; Vidigal et al., 2011).

It is worth mentioning that the consumption of omega- 3 can bring health benefits, acting in different functions in the body and in the control of neurodegenerative and allergic diseases, as well as diabetes, anemia, Parkinson's, Alzheimer's, cancer, among others. Thus, the increased consumption of omega-3 tends to bring benefits to consumers. However, the industries still 
face difficulties regarding the fortification of omega-3 in foods, since omega-3 (EPA and DHA) is majorly obtained from oily fish the nutrient brings with it the characteristic flavor from its source, considered unpleasant to the taste of consumers (Kolanowski et al., 1999).

Therefore, it is of great interest to industries to determine to what concentration they can add omega-3 without affecting the acceptance and without resulting in the sensorial rejection of products by consumers. This information was provided for the first time through this study, with the determination of the hedonic thresholds for concentrating omega- 3 in strawberry-flavored flan.

\section{Conclusion}

Information on the health benefits of omega-3 positively influenced the acceptance of the strawberry-flavored flan when omega- 3 was added in intermediate concentrations $(0.225 ; 0.400$ and $0.575 \mathrm{~g} / 100 \mathrm{~g})$. However, at extreme concentrations $(0.05$ and $0.75 \mathrm{~g} / 100 \mathrm{~g}$ ) the acceptance was not influenced. This occurred because at the lowest concentration, the product was accepted, and at the highest concentration the unpleasant taste characteristic of omega-3.

Through HTM, it was identified that it is possible to increase the addition of omega- 3 by $21 \%$ without sensory rejection of the flan. Therefore, by providing information on health benefits, it is possible to make greater additions of omega-3 without causing sensory rejection of the flan.

Thus, it is concluded that the information on health benefits can positively influence sensory acceptance, as long as there is sensory pleasure.

\section{Acknowledgments}

The authors thank the "Fundação de Amparo à Pesquisa do Estado de Minas Gerais (FAPEMIG)" for their financial support.

\section{References}

Abedi, F.; Sahmani, M.; Moghbelinejad, S.; Azad, M.; Rahmani, B.; Pishkhan, S.; Khoei, G.; Goldar, MZ.; \& Ghibi, N. (2020). Changes of WIF-1 and WT-1 genes expression following the anti-cancer effects of omega-3 and omega-6 on gastric cancer cells. Gene Reports, 21 (2), 100826. https://doi.org/10.1016/j.genrep.2020.100826.

Adkins, Y. \& Kalley, D. S. (2010). Mechanisms underlying the cardioprotective effects of omega-3 polyunsaturated fatty acids. The Journal of Nutritional Biochemistry, 21 (9), 781-792. https://doi.org/10.1016/j.jnutbio.2009.12.004.

Agostoni, C.; Bresson, J. L.; Fairweather-Tait, F.; Flynn, A.; Golly, I.; Korhonen, H.; Lagiou, P.; Løvik, M.; Marchelli, R.; Martin, A.; Moseley, B.; NeuhäuserBerthold, M.; Przyrembel, H.; Salminen, S.; Sanz, Y.; Strain, S.; Strobel, S.; Tetens, I.; Tomé, D.; Loveren, H.V. \& Verhagen, H. (2012). Panel on Dietetic Products, Nutrition and Allergies. Scientific Opinion related to the Tolerable Upper Intake Level of eicosapentaenoic acid (EPA), docosahexaenoic acid (DHA) and docosapentaenoic acid (DPA). EFSA Journal, 2815, 1-48. http://doi.org/10.2903/j.efsa.2012.2815.

Belkouch, M.; Hachem, M.; Elgot, A.; Van, A. L, Picq, M. \& Guichardant, M. (2016). The pleiotropic effects of omega-3 docosahexaenoic acid on the hallmarks of Alzheimer's disease. The Journal of Nutritional Biochemistry, 38, 1-11. https://doi.org/10.1016/j.jnutbio.2016.03.002.

Brasil. Portaria ${ }^{\circ} 31$ de 13 de janeiro de 1998. Regulamento técnico referente a alimentos adicionados de nutrientes essenciais. Agencia Nacional de Vigilância Sanitária. http://www.anvisa.gov.br [accessed 11 november 2020].

Comunian, T. A. \& Favaro-Trindade, C. S. (2016). Microencapsulation using biopolymers as an alternative to produce food enhanced with phytosterols and omega-3 fatty acids: A review. Food Hydrocolloids, 61, 442-457. https://doi.org/10.1016/j.foodhyd.2016.06.003.

Couet, C.; Krempf, M.; Lairon, D. \& Moulin, P. (2001). The omega 3 fatty acids and the cardiovascular system: nutritional benefits and claims. French Food Safety Agency, 1-67.

Daak, A. A.; Lopez-Toledano, M. A. \& Heeney, M. M. (2020). Biochemical and therapeutic effects of Omega-3 fatty acids in sickle cell disease. Complementary Therapies in Medicine, 52, 102482. https://doi.org/10.1016/j.ctim.2020.102482.

Euromonitor Intrnational, Top 10 Global Consumer Trends 2019, https:/go.euromonitor.com/white-paper-EC-2019-Top-10-Global-ConsumerTrends.html?fbclid=IwAR3QvOWw5rxxRQt_JwMCG_qM0TASpKpMGqNE5hOd0Gvhe-01qXe7H9RKe-U\#download-link . 
Gamba, M. M.; Lima Filho, T.; Della Lucia, S. M.; Vidigal, M. C. R. T.; Simiqueli, A. \& Minim, V. P. R. (2020). Performance of different scales in the hedonic thresholds methodology. Journal of Sensory Studies, 35 (5), 1-15. http://dx.doi.org/10.1111/joss.12592.

Gamba, M. M.; Lima Filho, T.; Torres, I. V.; Della Lucia, S. M. \& Minim, V. P. R. (2021). Random presentation minimizes the effect of expectation on the hedonic threshold methodology. Food Quality and Preference, 90, 104154. http://dx.doi.org/10.1016/j.foodqual.2020.104154.

Kerdiles, O.; Layé, S \& Calon, F. (2017). Omega-3 polyunsaturated fatty acids and brain health: Preclinical evidence for the prevention of neurodegenerative diseases. Trends in Food Science \& Technology, 69, 203-213. https://doi.org/10.1016/j.tifs.2017.09.003.

Kolanowski, W.; Swiderski, F. \& Berger, S. (1999). Possibilities of fish oil application for food products enrichment with $\omega$-3 PUFA. International Journal of Food Sciences and Nutrition, 50 (1), 39-49. https://doi.org/ 10.1080/096374899101409.

Let, M. B.; Jacobsen, C. \& Meyer, A. S. (2007). Lipid Oxidation in Milk, Yoghurt, and Salad Dressing Enriched with Neat Fish Oil or Pre-Emulsified Fish Oil. Journal of Agricultural and Food Chemistry, 55 (19), 7802-7809. https://doi.org/10.1021/jf070830x.

Lima Filho, T.; Della Lucia, S. M.; Minim, L. A.; Silva, R. C. S. N.; Silva, N. A. \& Minim, V. P. R. (2018). Validation of the hedonic threshold methodology in determining the hedonic rejection threshold. Journal of Sensory Studies, 33 (1), e12313. https://doi.org/10.1111/joss.12313.

Lima Filho, T.; Della Lucia, S. M.; Minim, L. A.; Silva, R. C. S. N.; Silva, N. A. \& Minim, V. P. R. (2017). Validation of the hedonic threshold methodology in determining the compromised acceptance threshold. Journal of Sensory Studies, 32 (2), e12255. https://doi.org/10.1111/joss.12255.

Lima Filho, T.; Minim, V. P. R.; Silva, R. C. S. N.; Della Lucia, S. M. \& Minim, L. A. (2015). Methodology for determination of two new sensory thresholds: Compromised acceptance threshold and rejection threshold. Food Research International, 76 (3), 561-566. https://doi.org/10.1016/j.foodres.2015.07.037.

Maki, K. C.; Palacios, O. M.; Bell, M. \& Toth, P. P. (2017). Use of supplemental long-chain omega-3 fatty acids and risk for cardiac death: An updated metaanalysis and review of research gaps. Journal of Clinical Lipidology, 11 (5), 1152-1160.e2. https://doi.org/10.1016/j.jacl.2017.07.010.

Maurício, A. F.; Carvalho, S. C.; Santo Neto, H. \& Marques, M. J. (2017). Effects of dietary omega-3 on dystrophic cardiac and diaphragm muscles as evaluated by $1 \mathrm{H}$ magnetic resonance spectroscopy: Metabolic profile and calcium-related proteins. Clinical Nutrition ESPEN, 20 , 60-7. https://doi.org/10.1016/j.clnesp.2017.03.005.

Minim, V. P. R. (2018). Análise sensorial: Estudos com consumidores, 4nd ed. Viçosa, UFV.

Muge, E. K.; Mbatia, N. B. \& Mwaniki, M. W. (2021). Development and Sensory Evaluation of Omega-3-Rich Nile Perch Fish Oil-Fortified Yogurt. Journal of Sensory Studies, 1, 1-7. https://doi.org/10.1155/2021/8838043.

Monahan, F. J.; Hutchings, S. C. \& Brunton, N. P. (2017). The effect of health claim information disclosure on the sensory characteristics of plant sterol-enriched turkey as assessed using the Check-All-That-Apply (CATA) methodology. Food Quality and Preference, 57 (1), 69-78. https://doi.org/10.1016/j.foodqual.2016.11.013.

Olson, D. \& Aryana, K. J. (2017). Omega-3 polyunsaturated fatty acids added to yogurt. Yogurt in Health and Disease Prevention, 7, 135-149. http://dx.doi.org/10.1016/B978-0-12-805134-4.00007-9.

Santana, J.; Araújo, C. I. A.; Cornejo, L.; Moreira, E. S.; Paula, M. C.; Carvalho, R. V.; Della Lucia, S. M. \& Lima Filho, T. (2020). Limiares hedônicos para redução de cloreto de sódio em biscoito salgado. Research, Society and Development, 9, p. e36491211376. https://doi.org/10.29327/cbcp2020.277013.

Shilpa, S. S.; Suchetha, K. N. \& Shetty, P. K. (2020). $\omega-6 / \omega-3$ fatty acid ratio as an essential predictive biomarker in the management of type 2 diabetes mellitus. Nutrition in Clinical Practice, 79, 110968. https://doi.org/10.1016/j.nut.2020.110968

Simiqueli, A. A.; Lima Filho, T.; Minim, L. A.; Oliveira, E. B.; Torres, I. V.; Vidigal, M. C. T. \& Minim, V. P. R. (2019). The W/O/W emulsion containing FeSO4 in the different phases alters the hedonic thresholds in milk-based dessert. Food Science and Technology, 99, 98-104. https://doi.org/10.1016/j.lwt.2018.09.020.

Story, M. J. (2020). $\omega-3$ polyunsaturated fatty acids and vitamin D: An essential combination for prevention and treatment of cancers. Biochemistry, 181, 100122. https://doi.org/10.1016/j.biochi.2020.11.019.

Singer, P.; Shapiro, H.; Theilla, M.; Anbar, R.; Singer, J.; Cohen, J. (2008). Anti-inflammatory properties of omega-3 fatty acids in critical illness: novel mechanisms and an integrative perspective. Intensive Care Medicine, 34, 1580. https://doi.org/10.1007/s00134-008-1142-4.

Tamtaji, O. R.; Taghizadeh, M.; Aghadavod, E.; Mafi, A.; Dadgostar, E.; Kakhaki, R. D.; Abolhassani, J. \& Asemi, Z. (2019). The effects of omega-3 fatty acids and vitamin E co-supplementation on gene expression related to inflammation, insulin and lipid in patients with Parkinson's disease: A randomized, doubleblind, placebo-controlled trial. Clinical Neurology and Neurosurgery, 176, 116-121. https://doi.org/10.1016/j.clineuro.2018.12.006.

Vidigal, M. C. T. R.; Minim, V. P. R.; Carvalho, N. B.; Milagres, M. P. \& Gonçalves, A. C. A. (2011). Effect of a health claim on consumer acceptance of exotic Brazilian fruit juices: Açaí (Euterpe oleracea Mart.), Camu-camu (Myrciaria dubia), Cajá (Spondias lutea L.) and Umbu (Spondias tuberosa Arruda). Food Research International, 44 (7), 1988-1996. https://doi.org/10.1016/j.foodres.2010.11.028.

Visconti, L. M.; Cotter, J. A.; Schick, E. E.; Daniels, N.; Viray, F. E.; Purcell, C. A.; Brotman, C. B. R.; Ruhman, K. E; Escobar, K. A. (2021). Impact of varying doses of omega-3 supplementation on muscle damage and recovery after eccentric resistance exercise. Metabolism Open, 12 , 100133. https://doi.org/10.1016/j.metop.2021.100133.

Yan, L.; Xie, Y.; Satyanarayanan, S. K.; Zeng, H.; Liu, Q.; Huang, M.; Ma, Y.; Wan, J.; Yao, X.; PinSu, K. \& Su, H. (2020). Omega-3 polyunsaturated fatty acids promote brain-to-blood clearance of $\beta$-Amyloid in a mouse model with Alzheimer's disease. Brain, Behavior, and Immunity, 85, 35-40. https://www.sciencedirect.com/science/article/abs/pii/S0889159118311759. 